\title{
Oral manifestation of multiple myeloma: a case report
}

- Jefferson da Rocha Tenório Faculdade de Odontologia, Universidade de São Paulo (USP), São Paulo, SP, Brazil; Faculdade de Odontologia, Universidade Federal do Rio de Janeiro (UFRJ), Rio de Janeiro, RJ, Brazil • Basílio de Almeida Milani Hospital Municipal do Campo Limpo, São Paulo, SP. Brazil • Bruno Fernandes Matuck Hospital das Clínicas da Faculdade de Medicina, Universidade de São Paulo (USP), São Paulo, SP, Brazil

ABSTRACT | Multiple myeloma (MM) is a relatively uncommon oncohematological condition characterized by abnormal proliferation of plasma cells. Oral manifestations of MM can occur in soft and intraosseous parts. We present a case of a 69-year-old man diagnosed with MM and undergoing chemotherapy, referred to the dental service complaining of a nodular swelling in the maxilla. An incisional biopsy was conducted and the histopathological analysis showed a monoclonal proliferation of plasma cells with a positive CD 138 immunophenotype, which allowed the diagnosis of extramedullary plasmacytoma. The outcome of the case was unfavorable and the patient died. We emphasize the importance of diagnosing MM extramedullary disease in the maxillofacial region.

DESCRIPTORS | Oral Diagnosis; Multiple Myeloma; Oral Cancer.

RESUMO | Manifestação oral de mieloma múltiplo: um estudo de caso • O Mieloma múltiplo (MM) é uma condição oncohematológica relativamente incomum caracterizada pela proliferação anormal de células plasmáticas. Manifestações orais de MM podem ocorrer tanto em partes moles quanto intraósseas. Apresentamos o caso de um homem de 69 anos, diagnosticado com MM e em tratamento quimioterápico, levado a tratamento odontológico por uma queixa de inchaço nodular no maxilar. Uma biópsia incisional foi realizada e a análise histopatológica revelou uma proliferação monoclonal de células plasmáticas com imunofenótipo CD 138, levando ao diagnóstico de plasmocitoma extramedular. O desfecho do caso foi desfavorável, com o paciente indo a óbito. Enfatizamos a importância do diagnóstico de MM extramedular na região maxilofacial.

DESCRITORES | Diagnóstico Bucal; Mieloma Múltiplo; Neoplasias Bucais.

CORRESPONDING AUTHOR | • Jefferson R. Tenório Faculdade de Odontologia, Universidade de São Paulo • Av. Prof. Lineu Prestes, 2227 São Paulo, SP, Brazil • 05508-000 E-mail: jeffersonrtenorio@gmail.com

- Received December 17, 2020 • Accepted August 19, 2021 


\section{INTRODUCTION}

Multiple myeloma (MM) is a lymphoid malignancy characterized by clonal proliferation of plasma cells. ${ }^{1}$ The prevalence of MM in the Brazilian population is uncertain, but it is a clinical condition that usually affects people between the 6th and 7 th decades of life and has an important impact on the quality of life of these individuals. ${ }^{2}$

MM usually begins as a monoclonal gammopathy of undetermined significance, progresses to the MM latent (asymptomatic) and finally becomes MM symptomatic, resulting in bone marrow failure and the development of lytic lesions disseminated throughout the skeletal system. ${ }^{3}$

The diagnosis of $\mathrm{MM}$ requires evidence of systemic involvement, and the acronym $\mathrm{CRAB}$ has been used to show the main signs observed (Calcium elevated; Renal failure; Anemia; Bone lesions) in affected patients. ${ }^{4}$ Among skeletal lesions, the most affected bones are the spine, ribs, skull, pelvis and femur, which often lead to pathological fractures. ${ }^{4}$ Soft tissues can also be infiltrated by neoplastic plasma cells, including the oral mucosa, which characterizes the extramedullary plasmacytoma. ${ }^{5}$
The objective of this work is to report the case of a patient in chemotherapy for MM who developed an extraosseous manifestation of this condition in the oral mucosa.

\section{CASE REPORT}

A 69-year-old man in treatment with melphalan, prednisone and thalidomide for MM was referred to the dental service of a hospital complaining of pain and difficulty in chewing because of a soft tissue lesion in the palate region on the right side. The patient was a chronic alcoholic, a smoker and had a general picture of weakness and malaise. The patient was unable to report the time of evolution of the lesion. On extraoral physical examination, no changes were observed. On intraoral examination, a notable nodular swelling in the region of the hard palate, maxillary tuber and alveolar ridge on the right side was observed (Figure 1). The lesion was firm on palpation, with areas of ulceration and spontaneous bleeding. Given the similarity with salivary gland tumors that occur frequently in the posterior region of the palate, the diagnostic hypotheses were of pleomorphic adenoma and mucoepidermoid carcinoma, and an incisional biopsy was performed under local anesthesia.

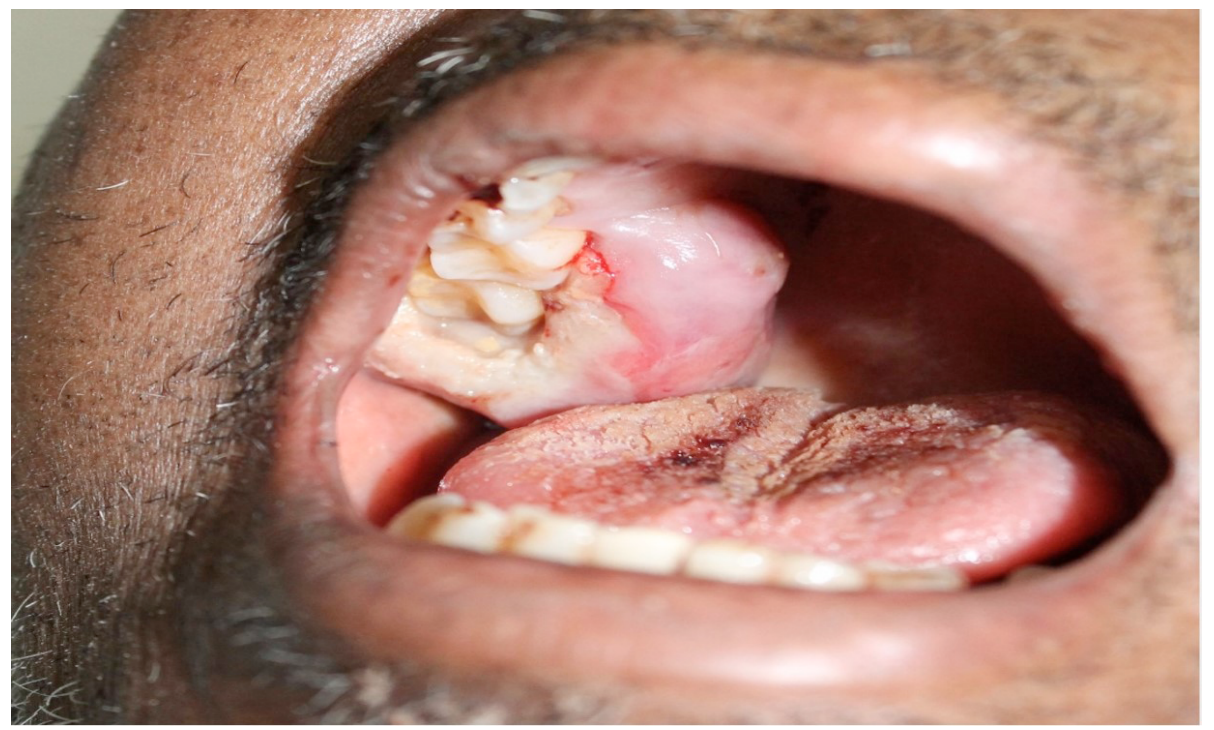

FIGURE 1 | Clinical aspect. Nodular swelling on hard palate, maxillary tuber and alveolar ridge of the maxilla with a wide area of ulceration and spontaneous bleeding. 
Microscopic analysis revealed a proliferation of plasmacytoid cells just below the mucosa. These cells were arranged in deep sheets. The tumor cells had mild pleomorphism and the tumor stroma was highly vascularized. Immunohistochemical analysis showed positivity for the immunoglobulin lambda chain and CD138, and negativity for CD2O, immunoglobulin kappa chain and LCA (leukocyte common antigen) (Figure 2). Based on clinical, histopathological and immunohistochemical findings, the diagnosis of extramedullary plasmacytoma was reached and the patient was referred to the hemotherapy sector for treatment. However, the patient died one month after the diagnosis of the lesion in the mouth due to renal complications of MM.
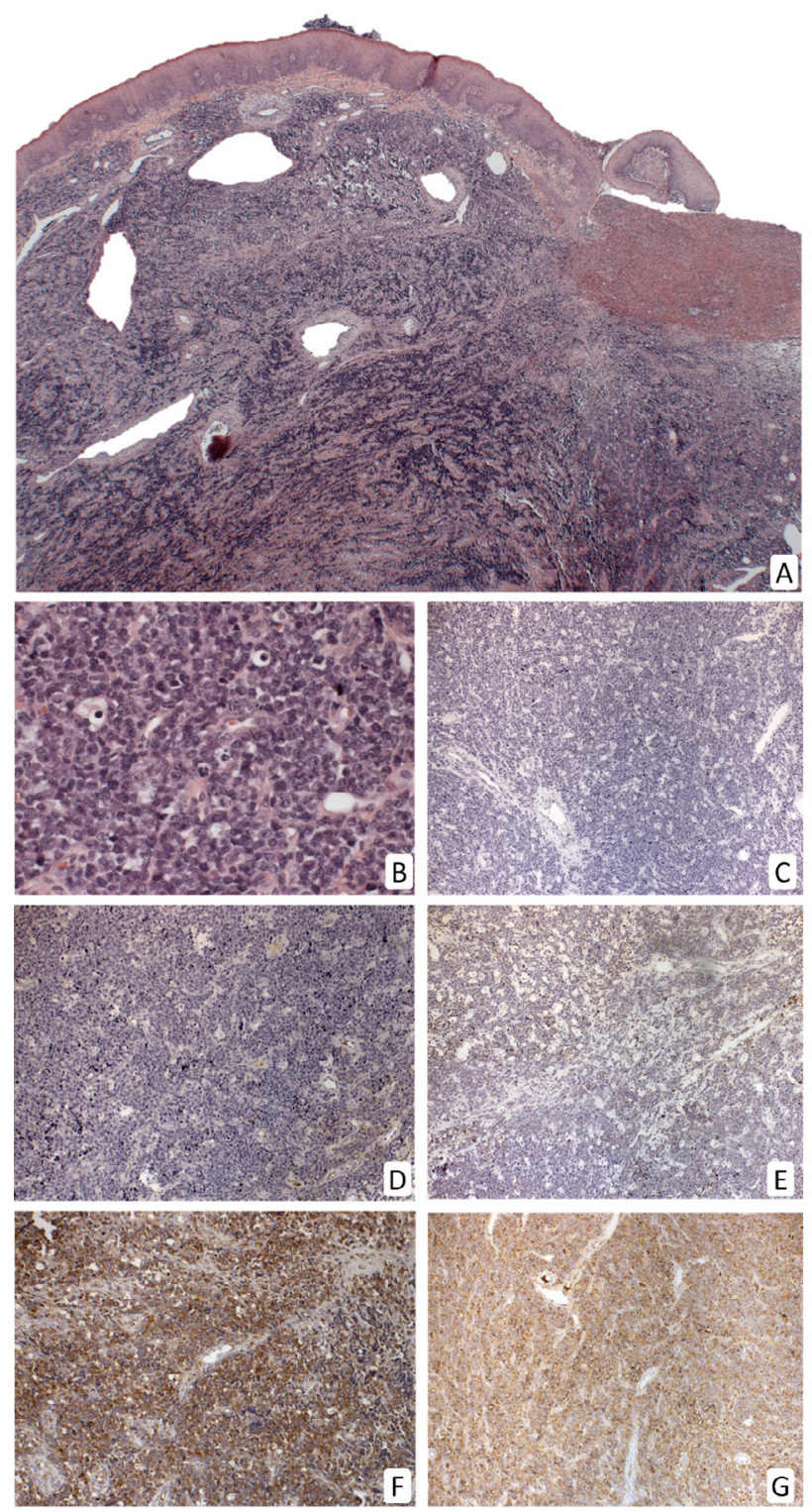

FIGURE 2 | Histopathological and immunohistochemical (IHC) examination. A: (Hematoxylin and Eosin, 40x) Neoplastic proliferation below the lining epithelium. B: (Hematoxylin and Eosin, 400×) Cells with plasmacytoid morphology, with eccentric nuclei and evident nucleoli. C: (IHC, 100x) Absence of immunostaining for CD20. D: (IHC, 100x) Absence of immunostaining for kappa chain. E: (IHC, 100×) Absence of immunostaining for LCA. F: (IHC, 100x) Positivity for CD138. G: (IHC, 100x) Positivity for lambda chain. 


\section{DISCUSSION}

Until recently, MM was considered an incurable disease with an extremely low survival rate. However, the introduction of new drugs (proteasome inhibitors, immunomodulatory drugs, monoclonal antibodies) greatly improved the survival of patients with MM. ${ }^{6}$ In this case, the patient was already undergoing treatment for $\mathrm{MM}$; however, using a conventional chemotherapy regimen.

To diagnose MM, a presence of $10 \%$ or more of clonal plasma cells in bone marrow examination or a biopsy proven plasmacytoma is necessary, associated with the presence of one or more myeloma-defining events. These events include the presence of one or more CRAB signals. 7 The patient in this case had already been diagnosed with MM based on bone marrow biopsy and CRAB signs and was under hematological monitoring.

Even though the patient in this report was already diagnosed with MM, the dentist should be aware of possible oral manifestations of MM. Bone pain, swelling, paraesthesia, amyloid deposits, dental mobility, gingival bleeding and root resorption are some of the findings described. ${ }^{8}$

A portion of patients affected by MM may develop a so-called extramedullary disease. There are several controversies surrounding the precise definition of this condition, but it is known that extramedullary disease can be observed at the time of diagnosis of MM or during relapse of MM. ${ }^{5}$

Extramedullary disease, as observed in our case, has been described since the 1940s, and can be characterized by diffuse infiltration of parenchymal organs, skin, soft tissues, pleura and central nervous system. ${ }^{5}$

Renal failure, which caused the death of the patient in this case, is a serious and common complication in MM. It occurs because of kidney overload due to the high presence of circulating light chain proteins, called Bence Jones proteins. The presence of renal failure implies a worse prognosis. ${ }^{9}$

\section{CONCLUSION}

$\mathrm{MM}$ is a relatively uncommon plasmacytic malignancy that can show oral manifestation resulting from an extramedullary disease, which requires an early stomatological diagnosis.

\section{REFERENCES}

1. Ludwig H, Miguel JS, Dimopoulos MA, Palumbo A, Garcia Sanz R, Powles R, et al. International Myeloma Working Group recommendations for global myeloma care. Leukemia. 2014;28(5):981-92. Doi: https://doi.org/10.1038/ leu.2013.293

2. Fairfield H, Falank C, Avery L, Reagan MR. Multiple myeloma in the marrow: pathogenesis and treatments. Ann $\mathrm{N}$ Y Acad Sci. 2016;1364(1):32-51. Doi: https://doi.org/10.1111/ nyas. 13038

3. Terpos E, Ntanasis-Stathopoulos I, Gavriatopoulou M, Dimopoulos MA. Pathogenesis of bone disease in multiple myeloma: from bench to bedside. Blood Cancer J. 2018;8(1):7. Doi: https://doi.org/10.1038/s41408-017-0037-4

4 Rajkumar SV. Updated Diagnostic Criteria and Staging System for Multiple Myeloma. Am Soc Clin Oncol Educ Book. 2016;35:e418-23. Doi: https://doi.org/10.1200/ EDBK_159009

5. Sevcikova S, Minarik J, Stork M, Jelinek T, Pour L, Hajek R. Extramedullary disease in multiple myeloma - controversies and future directions. Blood Rev. 2019;36:32-9. Doi: https:// doi.org/10.1016/j.blre.2019.04.002

6. Gerecke C, Fuhrmann S, Strifler S, Schmidt-Hieber M, Einsele H, Knop S. The Diagnosis and Treatment of Multiple Myeloma. Dtsch Arztebl Int. 2016;113(27-28):470-6. Doi: https://doi.org/10.3238/arztebl.2016.0470

7. Rajkumar SV. Multiple myeloma: 2016 update on diagnosis, risk-stratification, and management. Am J Hematol. 2016;91(7):719-34. Doi: https://doi.org/10.1002/ajh.24402

8. Almeida TMX, Cavalcanti EFF, Freitas AS, Magalhães RJP, Maiolino A, Torres SR. Can dentists detect multiple myeloma through oral manifestations? Rev Bras Hematol Hemoter. 2018;40(1):43-9. Doi: https://doi.org/10.1016/j. bjhh.2017.08.006

9. Heher EC, Rennke HG, Laubach JP, Richardson PG. Kidney disease and multiple myeloma. Clin J Am Soc Nephrol. 2013;8(11):2007-17. Doi: https://doi.org/10.2215/ CJN.12231212 